Gut, 1973, 14, 324-329

\title{
A comparative study of the major glycoprotein isolated from normal and neoplastic gastric mucosa
}

\author{
J. SCHRAGER AND M. D. G. OATES \\ From the Group Laboratory, Royal Albert Edward Infirmary, Wigan
}

SUMMARY The isolation and composition of glycoproteins from mucosae of normal stomachs, of stomachs with gastric ulcer, and of stomachs with carcinoma is described.

The glycoproteins from the mucosae of normal stomachs and with gastric ulcer showed virtually the same carbohydrate and amino acid content as the principal gastric glycoprotein isolated from gastric aspirates. They all revealed a common basic carbohydrate composition: galactose, fucose, glucosamine, and galactosamine were present in approximate molar ratios of 4:3:3:1.

The results suggest that the glycoproteins isolated from gastric aspirates from normal and neoplastic gastric mucosae share a number of structural features: (1) a protein core with a characteristic amino acid composition; (2) the range of sugars forming the carbohydrate side chains; (3) galactosamine approximately equimolar with the sum of threonine and serine; (4) galactose approximately equimolar with the sum of glucosamine and galactosamine; (5) absence of mannose; (6) a high carbohydrate content $(80-85 \%)$; and (7) blood group activity.

The neoplastic glycoproteins differed from the normal glycoproteins in that the quantitative relationships of the carbohydrate components of the neoplastic glycoproteins showed variations dividing the extracts investigated into groups, each group with a distinctive and constant carbohydrate composition. The blood group specificity of 15 out of 24 cases investigated differed from that of the hosts' red cells.

Detailed studies have recently been published on the immunology of extracts from normal and malignant gastric mucosae (Häkkinen, Järvi, and Grönroos, 1968; Kawasaki, Imasato, Funatsu, Noguchi, and Akiyama, 1970; Moore, Kupchik, Marcon, and Zamcheck, 1971; Ginsberg, 1971), but the information on the chemical composition of these extracts is very limited and the isolation of their components has, as yet, not been reported.

The isolation of the principal gastric glycoprotein using gel and gas-liquid chromatography has been described (Schrager and Oates, 1970; Schrager and Oates, 1971). The present paper reports the isolation of glycoproteins from both human normal and neoplastic gastric mucosae and a comparative study of their carbohydrate and amino acid composition using similar methods.

\section{Materials and Methods}

The following specimens were investigated : 24 surgical

Received for publication 1 February 1973. specimens of gastric carcinoma; five stomachs with gastric ulcer; and five stomachs obtained at necropsy within a few hours after death and which, as far as could be ascertained, there was no question of gastrointestinal disease.

Each specimen was washed clean of any traces of mucus and processed immediately on arrival in the laboratory. The tumour was carefully dissected from the surrounding tissue, cut into rectangular small pieces, and frozen onto the chucks of a Cambridge rocking microtome by using solid $\mathrm{CO}_{2}$. Sections were taken from all surfaces, stained, and examined microscopically. This process was continued until an area was reached consisting entirely of malignant glands. The malignant area thus isolated was processed as follows: shavings were collected into small plastic bottles containing $20 \mathrm{ml}$ of $0.1 \mathrm{M} \mathrm{NaH}_{2} \mathrm{PO}_{4}$ $\mathrm{Na}_{2} \mathrm{HPO}_{4}$ buffer, $\mathrm{pH} \mathrm{7 \cdot 4}$. The specimens were shaken for 20 to $30 \mathrm{~min}$ on a mechanical shaker and allowed to freeze slowly. After solidification, the temperature was decreased further by freezing in isopentanesolid $\mathrm{CO}_{2}$ mixture for 25 minutes. The bottles were placed at $4^{\circ} \mathrm{C}$ and allowed to thaw slowly overnight. 
They were shaken again for 20 to 30 minutes and the whole process was repeated. The repeated freezing and thawing ruptured the cells effectively. The suspension was then centrifuged at $2250 \mathrm{~g}$ for 15 minutes to pack down the cell debris. The deposit was discarded and the supernatant fluid was incubated with papain, $\mathrm{pH} 6.5$ at $65^{\circ} \mathrm{C}$, substrate: enzyme ratio $=20: 1$ (Spiro, 1966).

The five normal stomachs and the five stomachs with gastric ulcer were treated as follows: the ulcer area was dissected and discarded, the remaining mucosal lining and the mucosal lining of each of the normal stomachs were stripped as cleanly as possible from the underlying tissue and processed individually as described above.

Adequate quantities $(5 \mathrm{ml})$ from each papain digest were taken to determine the carbohydrate components and the sulphate and sialic acid content. The remaining material was eluted on Bio-gel P150 columns (with 0.05M NaCl). Pilot experiments had shown that the peak eluted on the void volume (the non-retarded fraction) contained $80-90 \%$ of the total carbohydrate put on the column. It was therefore selected as the subject matter of this study. The non-retarded fractions were assayed for their carbohydrate components, amino acid, sialic acid, and sulphate content. Two non-retarded fractions, one obtained from the normal and one from the neoplastic mucosae, were chromatographed again on Sepharose 4B.

GEL FILTRATION AND CHEMICAL ANALYSIS

The methods for the carbohydrate, amino acid, sulphate, and sialic acid analysis, and gel filtration procedure have already been described (Schrager and Oates, 1970).

\section{SEPHAROSE 4B COLUMN}

Sepharose 4B columns $(73 \times 1.5 \mathrm{~cm})$ were equilibrated with $0.05 \mathrm{M} \mathrm{NaCl}$. A non-retarded peak eluted on Bio-gel P150 was concentrated to $5 \mathrm{ml}$ and applied directly to the column. The single broad peak obtained was divided into two fractions and the carbohydrate and amino acid composition of each fraction determined.

According to the manufacturers, the approximate exclusion limits for polysaccharides is $5 \times 10^{6}$, for proteins $20 \times 10^{6} \mathrm{MW}$.

\section{AGGLUTINATION INHIBITION}

The method used was that described by Boorman and Dodd (1966).

\section{Results}

The proteolysed 24 neoplastic and 10 normal gastric mucosae (five surgical specimens with gastric ulcer and five obtained at necropsy) eluted on Bio-gel P150 provided similar elution profiles. Each extract was resolved into a non-retarded and retarded fraction, the former containing the bulk of the carbohydrate content put on the column and the latter consisting mainly of polypeptides (figs 1 and 2).

CARBOHYDRATE COMPOSITION OF THE NON-RETARDED FRACTION OF EXTRACTS FROM NORMAL AND NEOPLASTIC GASTRIC MUCOSAE

Acid hydrolysis of the non-retarded fractions of normal gastric mucosae yielded galactose, fucose, glucosamine, and galactosamine. The results are summarized in table I. No differences were found
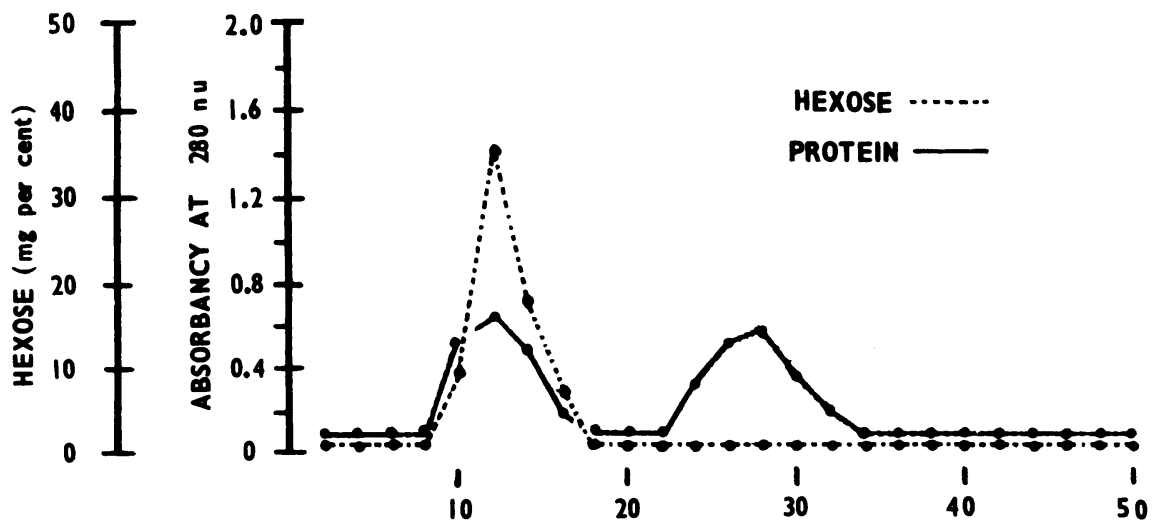

Fig. 1 Elution pattern from Bio-gel P.150 carried out with $0.05 \mathrm{M}$ sodium chloride. Fractions of $5 \mathrm{ml}$ were collected, elution rate $15 \mathrm{ml} / \mathrm{h}$.

FRACTION NUMBERS 

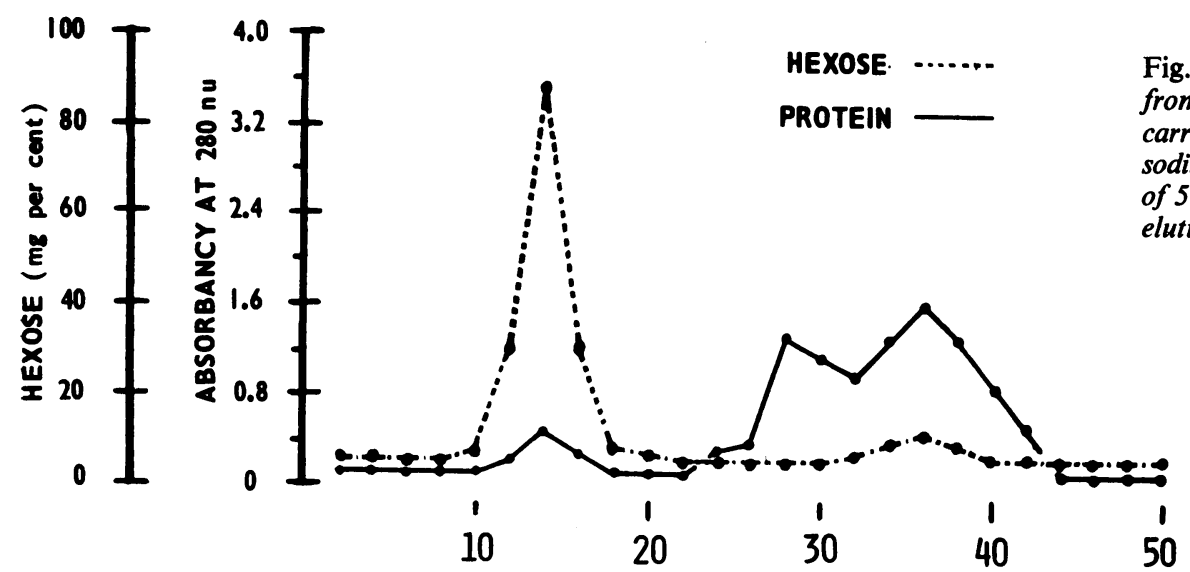

Fig. 2 Elution pattern from Bio-gel P.150 carried out with $0.05 M$ sodium chloride. Fractions of $5 \mathrm{ml}$ were collected, elution rate $15 \mathrm{ml} / \mathrm{h}$.

FRACTION NUMBERS

\begin{tabular}{|c|c|c|c|c|c|c|}
\hline & Galactose & Fucose & Glucosamine & Galactosamine & $\begin{array}{l}\text { Blood } \\
\text { Host }\end{array}$ & $\begin{array}{l}\text { Group Specificity } \\
\text { Extract }\end{array}$ \\
\hline Normal G & $\begin{array}{l}\text { Iucosa } \\
0.52(4.00) \\
0.71(3.81) \\
0.43(4.00) \\
0.67(4.00) \\
0.43(4.00)\end{array}$ & $\begin{array}{l}0.38(2.92) \\
0.53(2.84) \\
0.29(2.73) \\
0.49(2.9) \\
0.29(2.73)\end{array}$ & $\begin{array}{l}0.39(3.00) \\
0.56(3.00) \\
0.32(3.00) \\
0.50(3.00) \\
0.32(3.00)\end{array}$ & $\begin{array}{l}0.15(1.15) \\
0.21(1.14) \\
0.20(1.81) \\
0.37(2.20) \\
0.20(1.81)\end{array}$ & $\begin{array}{l}\mathbf{O} \\
\mathbf{O} \\
\mathbf{A} \\
\mathbf{A} \\
\mathbf{A}\end{array}$ & $\begin{array}{l}\text { H sec } \\
\text { H sec } \\
\text { A \& H sec } \\
\text { A \& H sec } \\
\text { A \& H sec }\end{array}$ \\
\hline Mucosa o & $\begin{array}{c}\text { chs with Gast } \\
1.02(4.20) \\
142(380) \\
0.58(3.94) \\
0.34(4.25) \\
0.55(3.77)\end{array}$ & $\begin{array}{l}0.74(3.21) \\
1.09(2.90) \\
0.41(2.82) \\
0.25(3.12) \\
0.38(2.7)\end{array}$ & $\begin{array}{l}0.71(3.00) \\
1.14(3.00) \\
0.44(3.00) \\
0.24(3.00) \\
0.44(3.00)\end{array}$ & $\begin{array}{l}0.23(1.00) \\
0.37(1.00) \\
0.29(1.90) \\
0.14(1.75) \\
0.22(1.52)\end{array}$ & $\begin{array}{l}\mathbf{O} \\
\mathbf{O} \\
\mathbf{A} \\
\mathbf{A} \\
\mathbf{A}\end{array}$ & $\begin{array}{l}\text { H sec } \\
\text { H sec } \\
\text { A \& H sec } \\
\text { A \& H sec } \\
\text { A \& H sec }\end{array}$ \\
\hline $\begin{array}{l}\text { Neoplasti } \\
\text { Group } 1\end{array}$ & $\begin{array}{l}\text { Mucosae } \\
0.28(0.88) \\
0.23(1.01)\end{array}$ & $\begin{array}{l}0.08(025) \\
0.17(0.73)\end{array}$ & $\begin{array}{l}0.31(1.00) \\
0.23(100)\end{array}$ & $\begin{array}{l}0.25(0.82) \\
0.23(1.00)\end{array}$ & $\begin{array}{l}\mathbf{A} \\
\mathbf{A}\end{array}$ & $\begin{array}{l}\text { Non-sec } \\
\text { H sec }\end{array}$ \\
\hline Group 2 & $\begin{array}{l}0.43(2.00) \\
0.26(2.00)\end{array}$ & $\begin{array}{l}0.26(1.21) \\
0.06(0.46)\end{array}$ & $\begin{array}{l}0.22(1.00) \\
0.13(1.00)\end{array}$ & $\begin{array}{l}0.23(1.04) \\
0.13(1.00)\end{array}$ & $\begin{array}{l}\mathbf{O} \\
\mathbf{A}\end{array}$ & $\begin{array}{l}\text { A \& H sec } \\
\text { H sec }\end{array}$ \\
\hline Group 3 & $\begin{array}{l}0.38(3.24) \\
0.64(2.77) \\
0.37(2.92) \\
0.73(3.17) \\
0.80(2.90) \\
0.34(3.30) \\
1.92(3.20) \\
1.20(2.89) \\
0.75(3.26) \\
1.00(2.94)\end{array}$ & $\begin{array}{l}0.11(0.93) \\
0.28(1.20) \\
0.11(0.93) \\
0.20(0.87) \\
0.64(2.40) \\
0.20(1.90) \\
1.76(2.93) \\
1.00(2.40) \\
0.33(1.43) \\
0.78(2.29)\end{array}$ & $\begin{array}{l}0.23(2.00) \\
0.46(2.00) \\
0.23(2.00) \\
0.46(2.00) \\
0.54(2.00) \\
0.20(2.00) \\
1.20(2.00) \\
0.83(2.00) \\
0.46(2.00) \\
0.68(2.00)\end{array}$ & $\begin{array}{l}0.23(1.95) \\
0.27(1.16) \\
0.11(0.96) \\
0.27(1.17) \\
0.28(1.03) \\
0.09(0.92) \\
0.65(1.08) \\
0.40(0.40) \\
0.23(1.00) \\
0.33(1.00)\end{array}$ & $\begin{array}{l}\mathbf{0} \\
\mathbf{O} \\
\\
\mathbf{O} \\
\mathbf{0} \\
\mathbf{O} \\
\mathbf{O} \\
\mathbf{0} \\
\mathbf{A} \\
\mathbf{0}\end{array}$ & $\begin{array}{l}\text { A \& H sec } \\
\text { Non-sec } \\
\text { A sec } \\
\text { H sec } \\
\text { H sec } \\
\text { H sec } \\
\text { A sec } \\
\text { H sec } \\
\text { H sec }\end{array}$ \\
\hline Group 4 & $\begin{array}{l}1.11(4.17) \\
0.27(3.59) \\
0.50(3.87) \\
0.20(3.86) \\
0.50(4.06) \\
0.49(3.87) \\
0.52(3.71) \\
0.46(3.87) \\
0.50(4.13) \\
0.34(3.90)\end{array}$ & $\begin{array}{l}0.86(3.25) \\
0.13(1.64) \\
0.13(1.01) \\
0.04(0.77) \\
0.24(1.95) \\
0.32(2.52) \\
0.40(2.85) \\
0.26(2.18) \\
0.26(2.18) \\
0.17(1.91)\end{array}$ & $\begin{array}{l}0.80(3.00) \\
0.24(3.00) \\
0.39(3.00) \\
0.17(3.00) \\
0.37(3.00) \\
0.38(3.00) \\
0.42(3.00) \\
0.36(3.00) \\
0.36(3.00) \\
0.26(3.00)\end{array}$ & $\begin{array}{l}0.36(1.36) \\
0.08(1.00) \\
0.17(1.33) \\
0.06(1.00) \\
0.14(1.15) \\
0.15(1.20) \\
0.16(1.14) \\
0.12(1.00) \\
0.10(0.86) \\
0.18(2.00)\end{array}$ & $\begin{array}{l}\mathbf{O} \\
\mathbf{A} \\
\mathbf{A} \\
\mathbf{A} \\
\mathbf{O} \\
\mathbf{O} \\
\mathbf{O} \\
\mathbf{O} \\
\mathbf{A} \\
\mathbf{O}\end{array}$ & $\begin{array}{l}\text { A \& H sec } \\
\text { H sec } \\
\text { A \& H sec } \\
\text { Non-sec } \\
\text { A sec } \\
\text { A sec } \\
\text { H sec } \\
\text { H sec } \\
\text { Non-sec } \\
\text { A \& H sec }\end{array}$ \\
\hline
\end{tabular}

Table I Carbohydrate composition of the non-retarded fractions of extracts from five normal gastric mucosae, five gastric mucosae of stomachs with a gastric ulcer, and 24 neoplastic gastric mucosae eluted on Bio-gel P150

${ }^{1}$ The quantities are in mmols/litre. The data in brackets show the quantitative relationship between galactose, fucose, glucosamine, and galactosamine. 
between the non-retarded fractions from the mucosae of stomachs with or without a gastric ulcer. Galactose, fucose, glucosamine, and galactosamine were present in an approximate molar ratio of $4: 3: 3: 1$ in specimens $1,2,3,6$, and 7 (blood group $O)$ and $4: 3: 3: 1 \cdot 75-2$ in specimens $5,8,9$, and 10 (blood group $\mathrm{A}$ ), the additional galactosamine being associated with blood group A. These results are virtually identical with previous findings relating to the principal glycoprotein isolated from gastric aspirates (Schrager and Oates, 1971).

The carbohydrate composition of the acid hydrolysates of the 24 non-retarded fractions of extracts from individual gastric neoplastic mucosae were determined by gas-liquid chromatography. The results are summarized in table II.

Each sample investigated contained galactose, fucose, glucosamine, and galactosamine. Galactose was approximately equimolar with the hexosamines (glucosamine + galactosamine).

Variations were noticed in the galactose, glucosamine, galactosamine ratios. The isolated glycoproteins were divisible with respect to the quantitative relationships of these sugars into four groups: galactose/glucosamine/galactosamine $=1: 1: 1$; galac- tose/glucosamine, galactosamine $=2: 1: 1$; galactose/glucosamine/galactosamine $=3: 2: 1$; galactose/glucosamine/galactosamine $=4: 3: 1$. The quantitative relationships were constant within each group; the variations were within the limits of the experimental error of the method used.

The fucose content varied from specimen to specimen and did not show the constancy noticed in the glycoproteins isolated from the normal gastric mucosae (table I).

\section{AMINo ACID ANALYSIS}

The amino acid analysis of two non-retarded fractions obtained from normal and two from neoplastic gastric mucosae was determined (table II). They showed the same characteristic composition as found in the gastric glycoproteins from aspirates (Schrager and Oates, 1971).

Threonine, serine, proline, alanine, and glycine made up $70-80 \%$ and the two hydroxyamino acids $45-50 \%$ of the protein core. The ratio of threonine to serine was found to be approximately 2:1. Quantitative relationships were found between the hydroxyamino acids and galactosamine (table III). The amount of threonine and serine approximated

\begin{tabular}{|c|c|c|c|c|}
\hline \multirow[t]{2}{*}{ Amino Acid } & \multicolumn{2}{|c|}{ Normal Gastric Mucosa } & \multicolumn{2}{|c|}{ Neoplastic Gastric Mucosa } \\
\hline & Specimen 1 & Specimen 2 & Specimen I & Specimen 2 \\
\hline Aspartic acid & 1.4 & 1.6 & $1 \cdot 1$ & 0.4 \\
\hline Threonine & $10 \cdot 0$ & 10.0 & 10.0 & $10 \cdot 0$ \\
\hline Serine & 6.6 & $5 \cdot 5$ & $5 \cdot 8$ & $5 \cdot 6$ \\
\hline Glutamic acid & $2 \cdot 3$ & $2 \cdot 0$ & $1 \cdot 5$ & 0.8 \\
\hline Proline & ND & 8.9 & $5 \cdot 8$ & $5 \cdot 4$ \\
\hline Glycine & 1.8 & $3 \cdot 0$ & 1.5 & $1 \cdot 3$ \\
\hline Alanine & $2 \cdot 7$ & $4 \cdot 0$ & - & 2.5 \\
\hline Valine & 0.9 & $1 \cdot 3$ & $1 \cdot 2$ & 1.0 \\
\hline Cystine & - & - & - & 0.2 \\
\hline Isoleucine & 0.6 & - & 0.5 & 0.4 \\
\hline Loucine & $1 \cdot 5$ & 1.8 & 1.0 & 0.5 \\
\hline Tyrosine & - & - & - & - \\
\hline Phenylalanine & 0.4 & - & - & - \\
\hline Lysine & 0.3 & $1 \cdot 3$ & 0.7 & 0.5 \\
\hline Histidine & 0.3 & 13 & 0.6 & 0.4 \\
\hline Arginine & 0.1 & 0.9 & 0.6 & 0.6 \\
\hline
\end{tabular}

Table II Amino acid composition of the non-retarded fractions of extracts from two normal gastric mucosae and two neoplastic gastric mucosae 1

'Values are in molar proportions (threonine $=10.0$ )

\begin{tabular}{|c|c|c|c|c|c|c|c|c|}
\hline \multirow{2}{*}{$\begin{array}{l}\text { Gastric } \\
\text { Mucosa }\end{array}$} & \multirow{2}{*}{$\begin{array}{l}\text { Total } \\
\text { Amino } \\
\text { Acids }\end{array}$} & \multirow{2}{*}{$\begin{array}{l}\text { Total } \\
\text { Sugars }\end{array}$} & \multirow{2}{*}{$\begin{array}{l}\text { Percentage of Sugars in } \\
\text { Glycoprotein }\end{array}$} & \multicolumn{2}{|l|}{ Amino Sugars } & \multirow[t]{2}{*}{ Threonine } & \multirow[t]{2}{*}{ Serine } & \multirow{2}{*}{$\begin{array}{l}\text { Blood Group } \\
\text { Specificity }\end{array}$} \\
\hline & & & & Glucosamine & Galactosamine & & & \\
\hline Normal & $\begin{array}{l}0.45 \\
0.42\end{array}$ & $\begin{array}{l}2 \cdot 94 \\
1 \cdot 59\end{array}$ & $\begin{array}{l}86 \\
78\end{array}$ & $\begin{array}{l}0.71 \\
0.44\end{array}$ & $\begin{array}{l}0.24 \\
0.22\end{array}$ & $\begin{array}{l}0 \cdot 16 \\
0 \cdot 10\end{array}$ & $\begin{array}{l}0.09 \\
0.06\end{array}$ & $\begin{array}{l}\text { H sec } \\
\text { A \& } \mathrm{H} \text { sec }\end{array}$ \\
\hline Neoplastic & $\begin{array}{l}0.94 \\
1.46\end{array}$ & $\begin{array}{l}3 \cdot 51 \\
5 \cdot 71\end{array}$ & $\begin{array}{l}78 \\
70\end{array}$ & $\begin{array}{l}0.83 \\
1.20\end{array}$ & $\begin{array}{l}0.48 \\
0.65\end{array}$ & $\begin{array}{l}0.28 \\
0.44\end{array}$ & $\begin{array}{l}0.17 \\
0.25\end{array}$ & $\begin{array}{l}\text { H sec } \\
\text { H sec }\end{array}$ \\
\hline
\end{tabular}

Table III Total amino acid, carbohydrate, threonine, and serine content of the eluted non-retarded fractions obtained from two normal gastric mucosae and two neoplastic gastric mucosae 
to that of galactosamine except in cases with blood group specificity A (table III); the glycoprotein with blood group specificity A contained galactosamine in excess of threonine and serine.

\section{SEPHAROSE}

Elution of the glycoproteins obtained from a normal and neoplastic gastric mucosae provided a single retarded peak. Each peak was divided into two fractions by combining the appropriate tubes. The two fractions of each of the re-chromatographed glycoproteins showed approximately the same carbohydrate (table IV).

\section{BLOOD GROUP SPECIFICITY}

The blood group specificity of the isolated glycoproteins from the normal gastric mucosae was that of the hosts' red cells. Fourteen out of the 24 malignant glycoproteins investigated showed alterations in their blood group activity deviating from that of the hosts' red cells (table I).

The sulphate and sialic acid content was variable and quantitatively uncertain, and therefore not recorded.

\section{Discussion}

The results of the study suggest that the glycoproteins isolated from normal gastric mucosae has virtually the same carbohydrate and amino acid composition as the principal gastric glycoprotein described previously (Schrager and Oates, 1970). The data also demonstrate that the glycoproteins from normal gastric aspirates, normal, and neoplastic gastric mucosae share the following structural features: (1) the protein core with a characteristic amino acid composition; (2) the range of sugars forming the carbohydrate side chains; (3) galactosamine approximately equimolar with the sum of threonine and serine; (4) galactose approximately equimolar with the sum of glucosamine and galactosamine (in glycoproteins with blood group specificity); (5) absence of mannose; (6) a high carbo- hydrate content $(70-86 \%$; and (7) blood group activity.

These seven parameters form distinguishing criteria to identify the three glycoproteins investigated. None of these parameters are to be found in any of the protein-polysaccharide complexes isolated from connective tissue or in any of the serum glycoproteins. The protein-polysaccharide complexes of connective tissue do not contain galactose but considerable quantities of uronic acid (except keratan sulphate which contains galactose but no uronic acid, it is exclusively found in cartilage, nucleus pulposus, and cornea and does not form part of the gastric wall or its mucosae) (Meyer, 1966; Muir, 1969). Any significant contamination with these substances would have been detected by the presence of uronic acid.

Very little is known about the glycoproteins of cell membranes, and the few data available show that they differ considerably both quantitatively and qualitatively from the gastric glycoproteins (Winzler, 1970).

The 'malignant glycoproteins' differed from the glycoproteins isolated from normal gastric mucosae as follows:

(a) The quantitative relationships of the carbohydrate components of the neoplastic glycoproteins showed variations, dividing the samples investigated into groups, each group with a distinctive and constant carbohydrate composition, differing from that of glycoproteins from normal gastric mucosae (except group 4).

(b) The blood group specificities of 14 out of the 24 cases investigated differed from those of the hosts' red cells.

The data provided by this investigation and the parameters enumerated above support our assumption that no other mucosubstances form a significant part of the fractions investigated.

The significant finding of this study is that the malignant cells contain a well formed secretory product synthesized to a pattern which is fundamentally similar to that of the principal glycoproteins isolated from gastric aspirates and normal

\begin{tabular}{|c|c|c|c|c|c|}
\hline Gastric Mucosa & & Galactose & Fucose & Glucosamine & Galactosamine \\
\hline Normal & $\begin{array}{l}\text { Fraction } 1 \\
\text { Fraction } 2\end{array}$ & $\begin{array}{l}0.28(4.00) \\
0.25(4.00)\end{array}$ & $\begin{array}{l}0.19(2.60) \\
0.17(2.82)\end{array}$ & $\begin{array}{l}0.21(3.00) \\
0.18(3.00)\end{array}$ & $\begin{array}{l}0.10(1.37) \\
0.08(1.31)\end{array}$ \\
\hline Neoplastic & $\begin{array}{l}\text { Fraction } 1 \\
\text { Fraction } 2\end{array}$ & $\begin{array}{l}7 \cdot 10(3.22) \\
7 \cdot 10(3.00)\end{array}$ & $\begin{array}{l}5.70(2.59) \\
1.50(1.43)\end{array}$ & $\begin{array}{l}4.40(2.00) \\
2.15(2.00)\end{array}$ & $\begin{array}{l}2.64(1.20) \\
1.05(0.98)\end{array}$ \\
\hline
\end{tabular}

Table IV Carbohydrate content of a non-retarded fraction obtained from an extract of a normal gastric mucosa and a neoplastic gastric mucosa rechromatographed on Sepharose $4 B(\text { mols/litre) })^{1}$

The data in brackets show the quantitative relationship between galactose, fucose, glucosamine, and galactosamine. 
gastric mucosae. The mutation of the normal mucus cell to a neoplastic cell is accompanied by varying modifications in the composition of the carbohydrate side chains dividing the specimens investigated into groups with respect to the quantitative relationships of the carbohydrate components.

The deviation of the blood group specificities from those of the hosts' red cells involved all four blood groups. These results differ from those of Häkkinen et al who found that the deviation did not affect patients belonging to blood group $\mathbf{A}$ (Häkkinen and Virtanen, 1967). It is interesting to note that the change from blood group $O$ to $A$ would involve the introduction of a new enzyme linking the terminal galactosamine to the carbohydrate side chain.

Whether the 'malignant' glycoproteins of each of the four groups identified have antigenic properties specific for each group and independent of the blood group specificities, has yet to be investigated.

We are grateful to Professor I. E. Gillespie, $\mathrm{Mr}$ H. B. Torrance, Mr J. B. Elder, Dr Ganguli, of the Royal Infirmary, Manchester, $\mathrm{Mr} \mathrm{L}$. Turner, Withington Hospital, Manchester, and the surgeons of the Royal Albert Edward Infirmary, Wigan, for the supply of surgical specimens, and we wish to thank Mrs Tunstall and Mrs Polding for their secretarial work in preparing the manuscript.
References

Boorman, K. E., and Dodd, B. E. (1966). An Introduction to Blood Group Serology, 3rd ed., pp. 61-66. Churchill, London. Little, Brown, Boston.

Ginsberg, A. L. (1971). Alterations in immunologic mechanisms in diseases of the gastrointestinal tract. Amer. J. dig. Dis., 16, 61-80.

Häkkinen, I. P. T., Järvi, O., and Grönroos, J. (1968). Sulphoglycoprotein antigens in the human alimentary canal and gastric cancer. An immunohistological study. Int. J. Cancer, 672-581.

Häkkinen, I. P. T., and Virtanen, S. (1967). The blood group activity of human gastric sulphoglycoproteins in patients with gastric cancer and normal controls. Clin. exp. Immunol., 2, 669-675.

Kawasaki, H., Imasato, K., Kimoto, E., Funatsu, H., Noguchi, Y., and Akiyama, K. (1970). Irregular distribution of the antigenic epithelial glycoprotein in gastric cancer. Kurume med. J., 17, 121-129.

Meyer, K. (1966). Mucopolysaccharides. Fed. Proc., 25, 1032-1034.

Moore, T. L., Kupchik, H. Z., Marcon, N., and Zamcheck, N. (1971). Carcinoembryonic antigen assay in cancer of the colon and pancreas and other digestive tract disorders. Amer. J. dig. Dis., 16, $1-7$.

Muir, H. (1969). The structure and metabolism of mucopolysaccharides (glycosaminoglycans) and the problem of the mucopolysaccharidoses. Amer. J. Med., 47, 673-690.

Kubo, T. (1971). Histologic appearance of gastric carcinoma in high and low mortality countries: comparison between Kyushu, Japan, and Minnesota, U.S.A. Cancer (Philad.), 28, 726-734.

Schrager, J., and Oates, M. D. G. (1970). Further observations on the principal glycoprotein of the gastric secretion. Digestion, 3, 231-242.

Schrager, J., and Oates, M. D. G. (1971). The isolation and composition of the major glycoprotein from human gastric aspirates. Gut, 12, 559-569.

Spiro, R. G. (1966). Analysis of sugars found in glycoproteins. In Methods in Enzymology, Vol. VIII. Complex Carbohydrates, edited by E. F. Neufeld and V. Ginsburg. Academic Press, New York and London.

Winzler, R. J. (1970). Carbohydrates in cell surfaces. Int. Rev. Cytol., 29, 77-125. 
Clinical Genetics 2nd edition edited by Arnold Sorsby. (Pp. xi + 646; illustrated. 117.00.) Butterworth Group, London. 1973. This is a comprehensive textbook of clinical genetics, with contributions from 31 outstanding British and American authorities. An opening section deals with general problems, such as the taking of a family history, pharmacogenetics, immunogenetics, and lethal and sublethal malformations. Twenty-one chapters are devoted to the genetic aspects of the individual specialities, such as metabolic disorders, the muscles, the central nervous system, the haemopoietic system, and cancer. A concluding chapter lists all known syndromes. The section on the alimentary tract is covered in detail by Dr R. B. McConnell.

The Chinese Medical Journal has restarted publication this year. Formerly it was in English only, but it is now in Chinese with shortened English translations. In view of the differences between western and Chinese medical experience it is of special interest to read. In the second issue there is an account of surgery in 1230 patients with oesophageal and gastric carcinoma.

\section{Corrections}

On page 288 of the paper by J. Schrager and M. D. G. Oates (Gut, 14, 324-329), column 1, line 16 of the discussion (in glycoproteins with blood group specificity) the phrase should read correctly (in glycoproteins with blood group specificity H).

We regret that in the paper by Penninckx et al (Gut, 14, 393-398) figs 2 and 3 have been transposed. 